\title{
Antiproliferative Activity of two compounds isolated from Artemisia sieberi
}

\author{
M. Taher M. El-Wassimy ${ }^{1}$, Mohamed-Elamir F. Hegazy ${ }^{2,3}$, Tarik A. Mohamed ${ }^{2}$, Sabry H. H. \\ Youns ${ }^{1}$, Hazem A. Al-Badry, \\ ${ }^{1}$ Chemistry Department, Faculty of Science, Sohag University, Sohag 82524, Egypt. \\ ${ }^{2}$ Chemistry of Medicinal Plants Department, National Research Centre, 33 El-Bohouth St., Dokki, Giza, \\ 12622, Egypt. \\ ${ }^{3}$ Department of Pharmaceutical Biology, Institute of Pharmacy and Biochemistry, University of Mainz, \\ Staudinger Weg 5, 55128 Mainz, Germany
}

Rec. 4 Mar, 2019 Accept. 1 Apr, 2019

\begin{abstract}
This study described the isolation and structure elucidation of secondary metabolites from,Artimisiasieberi (Asteraceae), known for its therapeutic and medicinal properties, it was used in both traditional and modern medicine.Artimisiasieberiwas collected at the flowering stage. Dried aerial parts were powdered and subjected to different chromatographic methods of extraction followed by different methods of purification through normal phase and reversed phase chromatography, eg. column chromatography (CC) and high performance liquid chromatography (HPLC), respectively.Phytochemical investigation of $A$. sieberiafforded a $3 \alpha, 8 \beta$ dihydroxygermacr-4(15),9-dien-6 $\alpha, 7 \beta, 11 \alpha \mathrm{H}, 12,6$-olide (1) and a flavonoid 3'-hydroxygenkwanin (2). The structures of the compounds were elucidated by means of spectroscopic analyses, including (EI-MS and 1D /2D NMR) techniques.Cytotoxic effects of these two known compounds were examined against, three different human cancer cell lines, MCF-7 (breast), HCT116 (colon) and HepG-2 (liver).Viability was assessed by the standard colorimetric assay using the tetrazolium, 3-[4,5-dimethylthiazol-2-yl]-2,5-diphenyl tetrazolium bromide (MTT) and can be regarded as an potent source of lead compounds in drugs development to combat cancer.
\end{abstract}

Keywords:Artimisiasieberi, $3 \alpha, 8 \beta$-dihydroxygermacr-4(15),9-dien-6 $\alpha, 7 \beta, 11 \alpha \mathrm{H}, 12,6$-olide, 3'-hydroxy-genkwanin, HepG-2, HCT-116, MCF-7, MTT.

\section{Introduction:}

Artemisia is one of the largest and most widely distributed genera belonging to the family Asteraceae. This genus composed of about 500 diverse species distributed mainly in the temperate zones of Europe, Asia and North America. These species are perennial, biennial and annual herbs or small shrubs (Bora \& Sharma, 2011; Wright, 2005). Artemisia species have a high economic value in several fields, as food plants and in the treatment of many diseases such as hepatitis, cancer, inflammation and infections by fungi, bacteria, and viruses. Furthermore, several species of Artemisia are used in folk medicine as anthelminthic, antispasmodic insecticidal, antiatherogenic, hepatoprotective, antihyperglycemic, antihypertensive and in traditional Chinese medicine for the treatment of gynecopathy, amenorrhea, bruise and rheumatic disease (Cho et al., 2015; Obolskiy, Pischel, Feistel, Glotov, \& Heinrich, 2011; Saadali, Boriky, Blaghen, Vanhaelen, \& Talbi, 2001; Stebbings, Beattie, McNamara, \& Hunt, 2015). Previous phytochemical reports of the genus Artemisia reveal that the Artemisia species are rich of terpenoids, flavonoids, coumarins, caffeoylquinic acids, sterols and acetylenic compounds .(Alwahibi et al., 2016)Among these bioactive compounds; artemisinin is a highly oxygenated sesquiterpene, containing 1,2,4-trioxane ring

\footnotetext{
* Corresponding author:

Dr. Hazem A. Al-Badry

凶hazem.14477@yahoo.com 
which is responsible for its antimalarial activity (Brown, 2010).Artemisinin exerts not only antimalarial activity but also profound cytotoxicity against tumor cells (Efferth, 2007).

Artemisia sieberior 'the desert worm wood' is locally knownas 'Shih' in Arabic countries and 'Dermaneh' inIran. A. sieberia prominent perennial dwarf greywoolly shrub that grows in open fields, road sidesand waste ground of the Irano-Turanian steppesof Spain, North Africa and the Middle East, Sinai,Jordan, Syria, Iraq, Iran and Afghanistan (Migahid, 1978). A. sieberiis a shrubby, perennial land rough plant, with the height of $30-50 \mathrm{~cm}$ spider web villies, and stems full of flowers straight rising from base. Leaves are oval and petiolate. Having petioles and full of rectangular banicule flowers, narrow and nearly hyacinth from (Bremer, 1993).

\section{Experimental:}

\section{General Experimental Procedures:}

${ }^{1} \mathrm{H}$ and ${ }^{13} \mathrm{C}$ NMR spectra were recorded in $\mathrm{CDCl}_{3}$ on a JEOL ECA-600 spectrometer $(600$ $\mathrm{MHz}$ for ${ }^{1} \mathrm{H}$ and $150 \mathrm{MHz}$ for ${ }^{13} \mathrm{C}$, respectively). All chemical shifts $(\delta)$ are given in ppm units with a reference to TMS as an internal standard and coupling constants $(J)$ are reported in Hz. EI-MS was performed on a Finnegan LCQ ion trap mass spectrometer and HR-EI-MS experiments were performed on Fourier transform ion cyclotron mass spectrometer. EI-MS experiments were performed using a Thermo ISQ Single Quadrupole system). High performance liquid chromatography (HPLC) was performed on an Agilent pump equipped with an AgilentG1314 variable wavelength UV detector at $254 \mathrm{~nm}$ and a semi-preparative reverse-phase column (Econosphere ${ }^{\mathrm{TM}}, \mathrm{RP}^{-\mathrm{C}_{18}}, 5 \mu \mathrm{m}, 250 \times$ $4.6 \mathrm{~mm}$, Alltech, Deerfield, IL, USA). Silica gel 60 (230-400 mesh) was used for column chromatography. Pre-coated silica gel plates (Kieselgel $60 \mathrm{~F}_{254}, 0.25 \mathrm{~mm}$ ) were used for TLC analyses. Spots were visualized by heating after spraying with $10 \% \mathrm{H}_{2} \mathrm{SO}_{4}$.

\section{Plant material:}

The aerial parts of Artemisiasieberi were collected from the north area of Saudi Arabia(near Zahaw) in April 2014, identified by a team of expert taxonomists at the Herbariumunit, and deposited at the Herbarium of the College of Pharmacy, King Saud University,Riyadh, Saudi Arabia (voucher number 16375).

\section{Extraction and isolation:}

Aerial parts $(1 \mathrm{~kg})$ of the plants were powdered and extracted twice with aqueous methanol( $80 \%)$ at room temperature. Combined extracts were evaporated in vacuo at $45^{\circ} \mathrm{C}$ to yielda dark brown residue ca. $85 \mathrm{~g}$. Initial separation was performed by means of liquid-liquidextraction of the crude extract with $n$-hexane, $\mathrm{CH}_{2} \mathrm{Cl}_{2}$, EtOAc, and $\mathrm{BuOH}$, respectively. $\mathrm{TheCH}_{2} \mathrm{Cl}_{2}$ fraction was subjected to silica gel column $(6 \times 120 \mathrm{~cm})$ eluting with $n$-hexane (3L)followed by a gradient of $n$-hexane- $\mathrm{CH}_{2} \mathrm{Cl}_{2}$ up to $100 \%$ $\mathrm{CH}_{2} \mathrm{Cl}_{2}$ and $\mathrm{CH}_{2} \mathrm{Cl}_{2}-\mathrm{MeOH}$ up to $15 \% \mathrm{MeOH}$ (2L each of the solvent mixture) to afford eight major fractions. The $n$-hexane- $\mathrm{CH}_{2} \mathrm{Cl}_{2}$ (1:3) fraction was chromatographed on silica gel column $(3 \times 90 \mathrm{~cm})$ elutedwith $n$-hexaneEtOAc $(6: 1,4: 1,2: 1)$ to afford $\mathbf{1}(25 \mathrm{mg})$ as fine white crystals. The $\mathrm{CH}_{2} \mathrm{Cl}_{2}(100 \%)$ fraction was chromatographed on a Sephadex LH-20 column $(3 \times 90 \mathrm{~cm})$ elutedwith $n$ hexane-EtOAc $(6: 1,4: 1,2: 1)$. Collected subfractions were re-chromatographedby RP HPLC using $\mathrm{MeOH} / \mathrm{H}_{2} \mathrm{O}(70-30 \%)$ to afford 2 (17 mg).

\section{Antiproliferativeof isolated compounds Chemicals Used:}

Dimethyl sulfoxide (DMSO), MTT and trypan blue dye was purchased from Sigma (St. Louis, Mo., USA). Fetal Bovine serum, DMEM, RPMI-1640, HEPES buffer solution, L-glutamine, gentamycin and $0.25 \%$ TrypsinEDTA were purchased from Lonza.

\section{Cell lines:}

MCF-7 cells (human breast cancer cell line), HepG-2 cells (human Hepatocellular carcinoma) and HCT-116 (colon carcinoma) were obtained from the American Type Culture Collection (ATCC, Rockville, MD). The cells were grown on RPMI-1640 medium supplemented with $10 \%$ inactivated fetal calf serum and $50 \mu \mathrm{g} / \mathrm{ml}$ gentamycin. The cells were maintained at $37{ }^{\circ} \mathrm{C}$ in a humidified 
atmosphere with $5 \% \quad \mathrm{CO}_{2}$ and were subcultured two to three times a week.

\section{Cell viability assay:}

For antitumor assays, the tumor cell lines were suspended in medium at concentration $5 \times 10^{4}$ cell/well in Corning $\AA$ 96-well tissue culture plates, then incubated for $24 \mathrm{~h}$. The tested compounds were then added into 96well plates (three replicates) to achieve twelve concentrations for each compound. Six vehicle controls with media or $0.5 \%$ DMSO were run for each 96 well plate as a control. After incubating for $24 \mathrm{~h}$, the numbers of viable cells were determined by the MTT test. Briefly, the media was removed from the 96 well plates and replaced with $100 \mu$ of fresh culture RPMI 1640 medium without phenol red then $10 \mu \mathrm{l}$ of the $12 \mathrm{mM}$ MTT stock solution ( $5 \mathrm{mg}$ of MTT in $1 \mathrm{~mL}$ of PBS) to each well including the untreated controls. The 96 well plates were then incubated at $37^{\circ} \mathrm{C}$ and $5 \% \mathrm{CO}_{2}$ for 4 hours. An $85 \mu 1$ aliquot of the media was removed from the wells, and $50 \mu \mathrm{l}$ of DMSO was added to each well and mixed thoroughly with the pipette and incubated at $37{ }^{\circ} \mathrm{C}$ for $10 \mathrm{~min}$. Then, the optical density was measured at $590 \mathrm{~nm}$ with the microplate reader (SunRise, TECAN, Inc, USA) to determine the number of viable cells and the percentage of viability was calculated as [1(ODt/ODc)]x100\% where ODt is the mean optical density of wells treated with the tested sample and ODc is the mean optical density of untreated cells. The relation between surviving cells and drug concentration isplotted to get the survival curve of each tumor cell line after treatment with thespecified compound.The $50 \%$ inhibitory concentration $\left(\mathrm{IC}_{50}\right)$, the concentration required to cause toxic effects in $50 \%$ of intact cells, was estimated from graphic plots of the dose response curve for each conc. using Graphpad Prism software (San Diego, CA. USA) (Gomha, Riyadh, Mahmmoud, \& Elaasser, 2015; Mosmann, 1983).

\section{Statistical Analysis:}

All results are expressed as mean \pm standard deviation (SD). Statistical differences between correlated samples were evaluated using Graphpad Prism software (San Diego, CA. USA).

\section{Results and Discussion:}

Structure Elucidation of compound 1 and 2

The molecular formula of compound 1 was established as $\mathrm{C}_{15} \mathrm{H}_{22} \mathrm{O}_{4}$ usingEI-MS data giving molecular ion peak at $\mathrm{m} / z 266$; DBE = 5 , suggesting the presence of five degrees of unsaturation.

The EI-MS mass spectral fragments at $\mathrm{m} / \mathrm{z}$

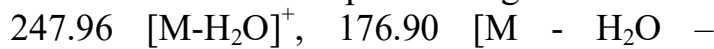
$\mathrm{CH}\left(\mathrm{CH}_{3}\right) \mathrm{COO}^{+}, \quad 106.97\left[\mathrm{M}-\mathrm{H}_{2} \mathrm{O}-\right.$ $\left.\mathrm{CH}\left(\mathrm{CH}_{3}\right) \mathrm{COO}-\mathrm{CH}(\mathrm{OH}) \mathrm{CH}_{2} \mathrm{CH}=\mathrm{CHCH}_{3}\right]^{+}$, indicating the presence of a carbonyl group, hydroxyl groups and lower fragments,suggesting the characteristic sesquiterpene nature of the isolated compound.

${ }^{1} \mathrm{H}-\mathrm{NMR},{ }^{13} \mathrm{C}-\mathrm{NMR}$ and $2 \mathrm{D} \mathrm{NMR}$ in $\left(\mathrm{CDCl}_{3}\right)$ spectroscopic data (Table 1) suggested the presence of a 5-membered lactone ring bounding to a germacradiene system.

The ${ }^{13} \mathrm{C}-\mathrm{NMR}$ andDEPT spectra revealed the presence of 15 carbons: threequaternary, six methine, four methylene and two methylcarbons.

The ${ }^{1}$ Hand ${ }^{13} \mathrm{C}$-NMR spectra of compound $\mathbf{1}$, revealed the presence of a proton signal at $\left(\delta_{\mathrm{H}} 2.50,1 \mathrm{H}, \mathrm{m}, \mathrm{H}-11\right)$ and carbon signal at $\left(\delta_{C} 42.1, \mathrm{C}-11\right)$ which is typical for a saturated lactone ring, indicating the absence of an exomethylene group at $\mathrm{C}-11$.

There is no evidence of $\mathrm{sp}^{2}$-hybridized methylene carbon peak and also the resonance of an upfield doublet $\left(\delta_{\mathrm{H}} 1.29,3 \mathrm{H}, \mathrm{d}, J=7.6\right.$ $\mathrm{Hz})$ and $\left(\delta_{C} 15.8\right)$, suggesting the presence of a methyl (Me-13) attached to C-11.

The ${ }^{1} \mathrm{H}-\mathrm{NMR}$ spectrum indicated the presence of an exo-methylene group at $\left(\delta_{\mathrm{H}}\right.$ $5.01,1 \mathrm{H}, \mathrm{d}, J=2.1 \mathrm{~Hz}, \mathrm{H}-15 \mathrm{a})$ and $\left(\delta_{\mathrm{H}} 5.28\right.$, $\mathrm{d}, J=2.1 \mathrm{~Hz}, \mathrm{H}-15 \mathrm{~b})$.Also, indicated the presence of a double bond between C-9 and C10 , supporting by the presence of a doublet at $\left(\delta_{\mathrm{H}} 5.12, \mathrm{~d}, J=9.6 \mathrm{~Hz}\right)$ typical for an olefinic hydrogen, which was assigned to H-9.

The position of the double bond can also be confirmed by HMBC correlations from $\mathrm{H}-9$ to $\mathrm{C}-1$ at $\left(\delta_{C} 36.5\right)$ and $\mathrm{C}-14$ at $\left(\delta_{C} / 17.4\right)$, from Me-14 to C-1 at $\left(\delta_{C} 36.5\right), \mathrm{C}-9$ at $\left(\delta_{C} 128.1\right)$ and to $\mathrm{C}-10$ at $\left(\underline{\delta}_{\underline{C}} 138.0\right)$. 
${ }^{1} \mathrm{H}-\mathrm{NMR}$ spectrum showed the presence of an olefinic methyl group at $\left(\delta_{H} 1.49,3 \mathrm{H}, \mathrm{s}\right.$, Me-14); a secondary methyl group at $\left(\delta_{H} 1.30\right.$, $3 \mathrm{H}, \mathrm{d}, J=6.9 \mathrm{~Hz}, \mathrm{Me}-13$ ).

Two hydroxymethine groups at $\left(\delta_{H} 3.71\right.$, $1 \mathrm{H}, \mathrm{m}, \mathrm{H}-3)$ and $\left(\delta_{H} 4.18,1 \mathrm{H}, \mathrm{t}, J=9.6 \mathrm{~Hz}, \mathrm{H}-\right.$ 8), the deshielded chemical shift of H-3, H-8 indicated the presence of two hydroxyl groups at position $\mathrm{C}-3$ and $\mathrm{C}-8$.

The signal at $\left(\delta_{H} 2.04-2.06\right)$ for methylene protons $\mathrm{H}-1$ appeared upfield compared to the previous compounds, which indicated the absence of the hydroxyl group at $\mathrm{C}-1$ in compound 1.

Two upfield methylene groups at $\left(\delta_{H} 1.89\right.$ $1.91,2 \mathrm{H}, \mathrm{m}, \mathrm{H}-2)$ and $\left(\delta_{H} 2.1,1 \mathrm{H}, \mathrm{dd}, J=\right.$ $16.5,4.4 \mathrm{~Hz}, \mathrm{H}-5 \mathrm{a} ; \delta_{H} 2.85,1 \mathrm{H}, \mathrm{dd}, J=16.5$, $2.1 \mathrm{~Hz}, \mathrm{H}-5 \mathrm{~b})$.

Also, showed two methineprotons at $\left(\delta_{H}\right.$ $1.91,1 \mathrm{H}, \mathrm{m}, \mathrm{H}-7)$ and $\left(\delta_{H} 2.50,1 \mathrm{H}, \mathrm{m}, \mathrm{H}-11\right)$ as well as the signal at $\left(\delta_{H} 3.78,1 \mathrm{H}, \mathrm{m}\right), \mathrm{H}-$ 6.The H-6 downfield value indicated the presence of a geminal functionality oxygen atoms in the molecule belonged to a lactone ring.

The ${ }^{13} \mathrm{C}-\mathrm{NMR}$ and DEPT spectra of compound 1 showed the resonance of 15 carbons, which were ascribed to: two methyl carbons at $\left(\delta_{C} 15.8\right.$ and 17.4 for $\mathrm{C}-13$ and C14), three methylene carbons at $\left(\delta_{C} 36.5,35.9\right.$ and 42.1 for $\mathrm{C}-1, \mathrm{C}-2$ and $\mathrm{C}-5$ ); one $\mathrm{sp}^{2}$ methylene carbon at $\left(\delta_{C} 113.4\right)$, corresponding to an exomethylenecarbon C-15; two methinecarbons at $\left(\delta_{C} 59.0\right.$ and 42.1 for C-7 and $\mathrm{C}-11)$ and one $\mathrm{sp}^{2}$ methinecarbon at $\left(\delta_{C}\right.$ 128.1), C-9, three oxygenated methine carbons $\left(\delta_{\mathrm{C}} 76.4,83.8\right.$, and 71.8 for C-3, C-6 and C-8); three quaternary carbons $\left(\delta_{C} 151.8,138.0\right.$ and 179.9 for C-4, C-10 and C-12), two of them are olefinic quaternary and the third belongs to carbonyl carbon of ester. These signals were determined to be quaternary carbons and did not exhibit ${ }^{1} \mathrm{H} /{ }^{13}$ Cone-bond correlations at HMQC experiment and these signals disappear in DEPT 135 experiment.

Most important COSY spectrum of compound 1 showed cross-peaks between the signal at $\left(\delta_{H} 1.30,3 \mathrm{H}, \mathrm{d}, J=7.6 \mathrm{~Hz}, \mathrm{Me}-13\right)$ with the signal at $\left(\delta_{H} 2.50,1 \mathrm{H}, \quad \mathrm{m}\right)$, corresponding to the $\mathrm{H}-11$ methine proton, the signal of olefinic proton $\left(\delta_{H} 5.12, \mathrm{~d}, J=9.6\right.$
$\mathrm{Hz}, \mathrm{H}-9)$ with the proton of $\left(\delta_{H} 4.18, \mathrm{IH}, \mathrm{t}, J=\right.$ $9.6 \mathrm{~Hz}, \mathrm{H}-8)$, the proton of $\left(\delta_{H} 4.18, \mathrm{IH}, \mathrm{t}, J=\right.$ $9.6 \mathrm{~Hz}, \mathrm{H}-8)$ with protons of $\mathrm{H}-7$ and $\mathrm{H}-$ 9.Additionally, there was cross-peaks between the signal at $\left(\delta_{H} 2.1,1 \mathrm{H}, \mathrm{dd}, J=16.5,4.4 \mathrm{~Hz}\right.$, H-5a) with the signals at $\left(\delta_{H} 2.85,1 \mathrm{H}, \mathrm{dd}, J=\right.$ $16.5,2.1 \mathrm{~Hz}, \mathrm{H}-5 \mathrm{~b})$ and $\left(\delta_{H} 3.78,1 \mathrm{H}, \mathrm{m}, \mathrm{H}-6\right)$, the signal of $\left(\delta_{H} 2.85,1 \mathrm{H}, \mathrm{dd}, J=16.5,2.1 \mathrm{~Hz}\right.$, $\mathrm{H}-5 \mathrm{~b}$ ) with the proton of $\mathrm{H}-5 \mathrm{a}$ and $\mathrm{H}-6$, the signal of exo-methylene proton $\left(\delta_{H} 5.01,1 \mathrm{H}\right.$, $\mathrm{d}, J=2.1 \mathrm{~Hz}, \mathrm{H}-15 \mathrm{a}$ ) with the proton of $\mathrm{H}-15 \mathrm{~b}$ at $\left(\delta_{H} 5.28, \mathrm{~d}, J=2.1 \mathrm{~Hz}\right)$, reciprocally (Table1).

On the basis of the HMBC correlations, the location of an exo-methylene group was assigned at position $\mathrm{C}-4 / \mathrm{C}-15$ which was confirmed from the correlation of $\mathrm{H}_{2}-15$ at $\left(\delta_{\mathrm{H}}\right.$ 5.01, 5.29), toC-3 at $\left(\delta_{C} 76.4\right), \mathrm{C}-5$ at $\left(\delta_{C} 42.1\right)$ and $\mathrm{C}-4$ at $\left(\delta_{C} 151.8\right)$.

The location of the methyl groups were established with the aid of longrange hydrogen-carbon correlations from the HMBC experiment which indicated the longrange correlations of Me-14 at $\left(\delta_{H} 1.49,3 \mathrm{H}, \mathrm{s}\right)$ with $\mathrm{C}-1$ at $\left(\delta_{C} 36.5\right)$, an olefinic carbon C-9 at $\left(\delta_{C} 128.1\right)$, a quaternary carbon $\mathrm{C}-10$ at $\left(\delta_{C}\right.$ $138.0)$, confirming that the methyl group was attached to the quaternary carbon at C-10. HMBC have no correlations between Me-14 and $\mathrm{C}-5$ which means no connectivity between C-5 and C-10.

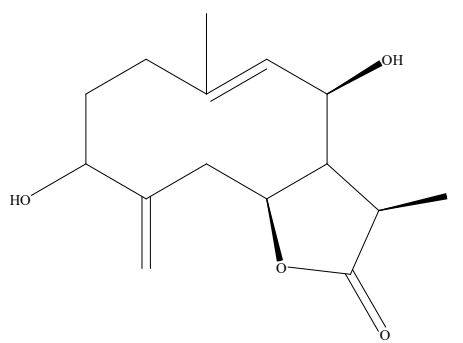

Another important correlation from a secondary methyl group Me-13 at $\left(\delta_{H} 1.303 \mathrm{H}\right.$, d, $J=7.6 \mathrm{~Hz})$ with C-11 at $\left(\delta_{C} 42.1\right), \mathrm{C}-7$ at $\left(\delta_{C} 59.0\right)$ and a carbonyl carbon $\mathrm{C}-12$ at $\left(\delta_{C} 179.9\right)$, confirming that Me-13 was connected to $\mathrm{C}-11$.

The position of the lactone ring was deduced from the presence of long range correlations of $\mathrm{H}-11$ at $\left(\delta_{H} 2.50, \quad \mathrm{~m}\right)$ with $\left(\delta_{C} 59.0, \mathrm{C}-7\right),\left(\delta_{C} 71.8, \mathrm{C}-8\right)\left(\delta_{C} 179.9, \mathrm{C}-\right.$ $12)$ and methyl carbon $\left(\delta_{C} 15.8, \mathrm{C}-13\right) ; \mathrm{H}-7$ at 
$\left(\delta_{\mathrm{H}} 1.91\right) \quad$ with $\left(\delta_{C} 83.8, \mathrm{C}-6\right),\left(\delta_{C} 71.8, \mathrm{C}-8\right)$ $\left(\delta_{C} 128.1, \quad \mathrm{C}-9\right)$ andH-6at $\left(\delta_{H}\right.$ 3.78) with $\left(\delta_{C} 151.8, \mathrm{C}-4\right),\left(\delta_{C} 71.8, \mathrm{C}-8\right)$, confirming that the lactone ring at $\mathrm{C}-6 / \mathrm{C}-7$.

The above information led to the characterization of compound 1 as $3 \alpha, 8 \beta$ - dihydroxygermacr-4(15),9-dien$6 \alpha, 7 \beta, 11 \alpha \mathrm{H}, 12,6$-olide.

The NMR data were in good agreement with previously published data (Gordon, Van Derveer, \& Zalkow, 1981; Mohamed et al., 2017).

\begin{tabular}{|c|c|c|c|c|}
\hline Position of 1 & $\boldsymbol{\delta}_{\boldsymbol{H}}$ mult. $(J$ in Hz) & $\boldsymbol{\delta}_{\boldsymbol{C}}$ (Type) & $\begin{array}{c}\text { COSY } \\
{ }^{1} H_{\leftrightarrow}{ }^{1} H\end{array}$ & $\begin{array}{c}\text { HMBC } \\
{ }^{1} \mathrm{H}^{13} \mathrm{C}\end{array}$ \\
\hline $\mathrm{H}_{2}-1$ & $2.04-2.06 \mathrm{~m}$ & $36.5\left(\mathrm{CH}_{2}\right)$ & $\mathrm{H}-2$ & C-2, C-3, C-10, C-14, C-9 \\
\hline $\mathrm{H}_{2}-2$ & $1.89-1.91 \mathrm{~m}$ & $35.9\left(\mathrm{CH}_{2}\right)$ & H-1, H-3 & C-1, C-3, C-4,C-10, C-14 \\
\hline H-3 & $3.71 \mathrm{~m}$ & $76.4(\mathrm{CH})$ & $\mathrm{H}-2$ & $\mathrm{C}-4, \mathrm{C}-5, \mathrm{C}-15$ \\
\hline $\mathrm{H}-4$ & ........ & $151.8(\mathrm{C})$ & .......... & 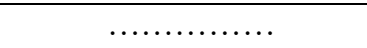 \\
\hline $\mathrm{H}-5_{\mathrm{a}}$ & $2.13 \mathrm{dd}(16.5,4.4)$ & \multirow{2}{*}{$42.1\left(\mathrm{CH}_{2}\right)$} & $\mathrm{H}-5_{\mathrm{b}}, \mathrm{H}-6$ & $\mathrm{C}-4, \mathrm{C}-6, \mathrm{C}-15$ \\
\hline $\mathrm{H}-5_{\mathrm{b}}$ & $2.85 \mathrm{dd}(16.5,2.1)$ & & $\mathrm{H}-5_{\mathrm{a}}, \mathrm{H}-6$ & $\mathrm{C}-4, \mathrm{C}-6, \mathrm{C}-15$ \\
\hline H-6 & $3.78 \mathrm{~m}$ & $83.8(\mathrm{CH})$ & $\mathrm{H}-7, \mathrm{H}-5_{\mathrm{a}}, \mathrm{H}-5_{\mathrm{b}}$ & $\mathrm{C}-4, \mathrm{C}-8$ \\
\hline $\mathrm{H}-7$ & $1.91 \mathrm{~m}$ & $59.0(\mathrm{CH})$ & H-11, H-8 & $\mathrm{C}-5, \mathrm{C}-8, \mathrm{C}-9$ \\
\hline $\mathrm{H}-8$ & $4.18 \mathrm{t}(9.6)$ & $71.8(\mathrm{CH})$ & H-7, H-9 & $\mathrm{C}-11, \mathrm{C}-7, \mathrm{C}-10$ \\
\hline H-9 & $5.12 \mathrm{~d}(9.6)$ & $128.1(\mathrm{CH})$ & $\mathrm{H}-8$ & $\mathrm{C}-14, \mathrm{C}-1$ \\
\hline $\mathrm{H}-10$ & $\ldots \ldots \ldots$ & $138.0(\mathrm{C})$ & $\ldots \ldots \ldots \ldots \ldots$ & $\ldots \ldots \ldots \ldots \ldots$ \\
\hline H-11 & $2.50 \mathrm{~m}$ & $42.1(\mathrm{CH})$ & $\mathrm{H}-13, \mathrm{H}-7$ & $\mathrm{C}-13, \mathrm{C}-12, \mathrm{C}-7, \mathrm{C}-8$ \\
\hline $\mathrm{H}-12$ & $\ldots \ldots \ldots \ldots \ldots$ & $179.9(\mathrm{C})$ & $\ldots \ldots \ldots \ldots \ldots$ & ............. \\
\hline $\mathrm{H}-13$ & $1.30 \mathrm{~d}(7.6)$ & $15.8\left(\mathrm{CH}_{3}\right)$ & $\mathrm{H}-11$ & $\mathrm{C}-11, \mathrm{C}-7, \mathrm{C}-12$ \\
\hline H-14 & $1.49 \mathrm{~s}$ & $17.4\left(\mathrm{CH}_{3}\right)$ & n.w. & C-10, C-9, C-1 \\
\hline $\mathrm{H}-15_{\mathrm{a}}$ & $5.01 \mathrm{~d}(2.1)$ & \multirow{2}{*}{$113.0\left(\mathrm{CH}_{2}\right)$} & $\mathrm{H}-5_{\mathrm{b}}$ & $\mathrm{C}-3, \mathrm{C}-4, \mathrm{C}-5$ \\
\hline $\mathrm{H}-15_{\mathrm{b}}$ & $5.28 \mathrm{~d}(2.1)$ & & $\mathrm{H}-5_{\mathrm{b}}$ & $\mathrm{C}-3, \mathrm{C}-4, \mathrm{C}-5$ \\
\hline
\end{tabular}

Table 1: ${ }^{1} \mathrm{H}(600 \mathrm{MHz}),{ }^{13} \mathrm{C}-\mathrm{NMR}(150 \mathrm{MHz}) \mathrm{DEPT}, \mathrm{H}^{1}-\mathrm{H}^{1} \mathrm{COSY}$ and HMBC spectral data of compound 1recorded in $\mathrm{CDCl}_{3}$

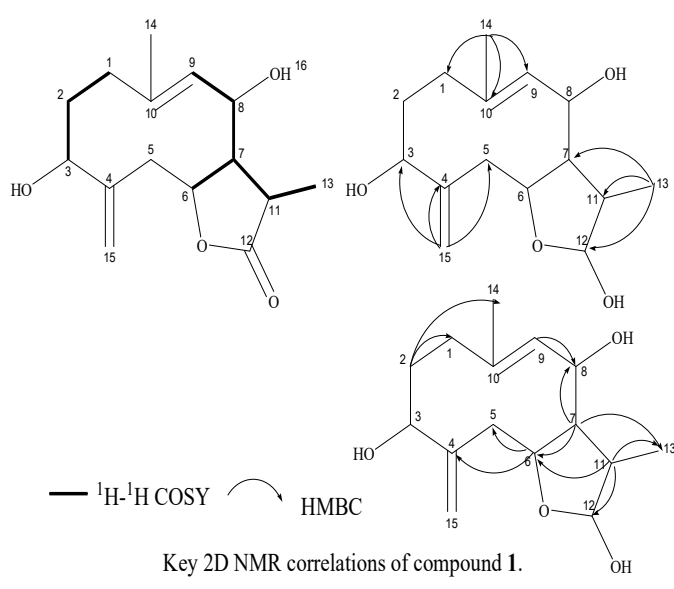

The molecular formula of compound $\mathbf{2}$ was established as $\mathrm{C}_{16} \mathrm{H}_{12} \mathrm{O}_{6}$ usingEI-MS data giving molecular ion peak at $\mathrm{m} / \mathrm{z} 299.96 \mathrm{DBE}$ $=11$, suggesting the presence of eleven degrees of unsaturation.
The EI-MS mass spectral fragments at $\mathrm{m} / \mathrm{z}$

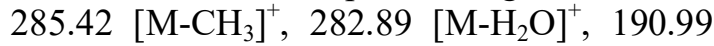
$\left[\mathrm{M}-\mathrm{ph}-(\mathrm{OH})_{2}\right]^{+}$and 158.15 ([M- ph- $(\mathrm{OH})_{2}$, $\left.\mathrm{OCH}_{3}\right]^{+}$), confirming the presence of an oxygenated methyl, phenyl groups and hydroxyl groups.

The complete structure of compound $\mathbf{2}$ was elucidated by the use of ${ }^{1} \mathrm{H}-\mathrm{NMR}$ and ${ }^{13} \mathrm{C}$ NMR which provided an evidence for a flavonoid skeleton (Table 2).

The ${ }^{1} \mathrm{H}-\mathrm{NMR}$ (DMSO) and ${ }^{13} \mathrm{C}-\mathrm{NMR}$ (DMSO) spectra of compound 2 showed the presence of signals at $\delta_{H} 12.99(1 \mathrm{H}, \mathrm{s}, \mathrm{OH}-5)$, six sp ${ }^{2}$ methine groups at $\delta_{H} 7.55(1 \mathrm{H}, \mathrm{d}, J=$ $\left.8.0 \mathrm{~Hz}, \mathrm{H}-6^{\prime}\right) ; \delta_{C} 120.7\left(\mathrm{C}^{-} 6^{\prime}\right), 7.52(1 \mathrm{H}, \mathrm{s}, \mathrm{H}-$ $\left.2^{\prime}\right) ; \delta_{C} 110.4\left(\mathrm{C}-2^{\prime}\right), 6.94(1 \mathrm{H}, \mathrm{d}, J=12.0 \mathrm{~Hz}$, H-5'); $\delta_{C} 116.2\left(\mathrm{C}-5^{\prime}\right), \delta_{H} 6.84(1 \mathrm{H}, \mathrm{s}, \mathrm{H}-3) ; \delta_{C}$ $103.5(\mathrm{C}-3), \delta_{H} 6.5(1 \mathrm{H}, \mathrm{s}, \mathrm{H}-8) ; \delta_{C} 94.5(\mathrm{C}-$ 8), $\delta_{H} 6.19(1 \mathrm{H}, \mathrm{s}, \mathrm{H}-6), \delta_{C} 99.2$ (C-6), one oxygenated methyl group $\delta_{H} 3.86(3 \mathrm{H}, \mathrm{s}$, 
$\left.\mathrm{OCH}_{3}\right) ; \delta_{C} 56.0\left(4-\mathrm{OCH}_{3}\right)$, nine tertiary $\mathrm{sp}^{2}$ carbon atom at $\delta$ : $182.2(\mathrm{C}-4), 164.6(\mathrm{C}-7)$, 164.2 (C-2), 161.8 (C-5), 157.8 (C-9), 151.1 (C-4'), 148.4 (C-3'), 122 (C-1'), 104.1 (C-10). All these data were in good agreement with those of 3'-hydroxy-genkwanin.

The molecular weight suggested the occurrence of a further oxygen function which must be a hydroxyl, carbonyl and ether groups. The presence of seven oxygenated carbon atoms was confirmed by the presence of the seven signals at $\delta$ : $181.8(\mathrm{C}-4), 165.1(\mathrm{C}-7)$, 164.2 (C-2), 161.8 (C-5), 157.8 (C-9), 151.1 (C-4'), $148.2\left(\mathrm{C}-3^{\prime}\right)$.<smiles>COc1cc(O)c2c(=O)cc(-c3ccc(O)c(O)c3)oc2c1</smiles>

(2)

Therefore, compound 2 is characterized as3'-hydroxy-genkwanin(Park et al., 2014; Zeng \& Quesheng).

\begin{tabular}{|c|c|c|}
\hline Position & $\boldsymbol{\delta}_{\boldsymbol{H}}$ mult. $(J$ in Hz) & $\boldsymbol{\delta}_{\boldsymbol{C}}($ Туре $)$ \\
\hline $\mathrm{H}-1$ & $\ldots \ldots \ldots$ & ......... \\
\hline $\mathrm{H}-2$ & & $164.2(\mathrm{C})$ \\
\hline $\mathrm{H}-3$ & $6.83, \mathrm{~s}$ & $103.5(\mathrm{CH})$ \\
\hline $\mathrm{H}-4$ & $\ldots \ldots \ldots$ & $182.2(\mathrm{C})$ \\
\hline H-5 & $\ldots \ldots \ldots$ & $161.8(\mathrm{C})$ \\
\hline H-6 & $6.19, \mathrm{~s}$ & $99.2(\mathrm{CH})$ \\
\hline $\mathrm{H}-7$ & $\ldots \ldots \ldots \ldots$ & $164.6(\mathrm{C})$ \\
\hline $\mathrm{H}-8$ & 6.5 & $94.5(\mathrm{CH})$ \\
\hline H-9 & ......... & $157.8(\mathrm{C})$ \\
\hline $\mathrm{H}-10$ & $\ldots \ldots \ldots \ldots$ & $104.1(\mathrm{C})$ \\
\hline H-1' & f........... & $122(\mathrm{C})$ \\
\hline H-2' & $7.52 \mathrm{~s}$ & $110.4(\mathrm{CH})$ \\
\hline H-3' & $\ldots \ldots \ldots$ & $148.4(\mathrm{C})$ \\
\hline H-4' & $\ldots \ldots \ldots$ & $151.1(\mathrm{C})$ \\
\hline H-5' & $6.94 \mathrm{~d}(12)$ & $116.2(\mathrm{CH})$ \\
\hline H-6' & $7.55 \mathrm{~d}(8)$ & $120.7(\mathrm{CH})$ \\
\hline$-\mathrm{OCH}_{3}$ & $3.86 \mathrm{~s}$ & $56\left(\mathrm{CH}_{3}\right)$ \\
\hline
\end{tabular}

Table2: ${ }^{1} \mathrm{H}(600 \mathrm{MHz}),{ }^{13} \mathrm{C}-\mathrm{NMR}(125 \mathrm{MHz})$ and DEPT spectral data of compound 2recorded in DMSO.

\section{Antiproliferative activity:}

To evaluate the antiproliferative activity of compound 1, their anti-proliferative potential against MCF-7 cells (human breast cancer cell line), HepG-2 cells (human Hepatocellular carcinoma) and HCT-116 (colon carcinoma) were assessed using a cell viability assay with 3-(4,5-dimethylthiazol-2-yl)-2,5-

diphenyltetrazolium bromide (MTT). The cells were treated at concentrations $500 \mu \mathrm{g} / \mathrm{mL}, 250$ $\mu \mathrm{g} / \mathrm{mL}, \quad 125 \mu \mathrm{g} / \mathrm{mL}, \quad 62.5 \mu \mathrm{g} / \mathrm{mL}, \quad 31.25$ $\mu \mathrm{g} / \mathrm{mL}, \quad 15.6 \mu \mathrm{g} / \mathrm{mL}, \quad 7.8 \mu \mathrm{g} / \mathrm{mL}$ and 3.9 $\mu \mathrm{g} / \mathrm{mL}$ for $24 \mathrm{~h}$. The anticancer drug, cisplatin was used as a positive control. Compound 1 showed $\mathrm{IC}_{50}(146 \pm 3.5,173 \pm 4.6,115 \pm 3.4)$ $\mu \mathrm{g} / \mathrm{ml}$. respectively(Fig. 1-3) andcompound 2showed $\mathrm{IC}_{50}(13.6 \pm 0.3,22.5 \pm 0.3,15.4 \pm$ $0.5) \mu \mathrm{g} / \mathrm{ml}$. respectively(Fig. 4-6).

\section{Conclusion:}

Investigation of Artimisiasieberiaffordeda $3 \alpha, 8 \beta$-dihydroxygermacr-4(15),9-dien$6 \alpha, 7 \beta, 11 \alpha \mathrm{H}, 12,6$-olide and 3'-Hydroxy-genkwanin; have potential to be anti-cancer drugs.

\section{References:}

Alwahibi, L. H., Abdel-Mageed, W. M., Abdelkader, M., Bayoumi, S. A., Basudan, O. A., El-Gamal, A. A., \& Bolla, K. (2016). Sesquiterpene Lactones and Flavonoids from Artemisia sieberi. IJPPR, 8(4), 639644.

Bora, K.S.\& Sharma, A. (2011). The genus Artemisia: a comprehensive review. Pharmaceutical Biology, 49(1), 101109.

Bremer, K. (1993). The generic monograph of the Asteraceae-Anthemideae. Bull. Nat. Hist. Mus. London (Bot.), 23, 71177.

Brown, G.D. (2010). The biosynthesis of artemisinin (Qinghaosu) and the phytochemistry of Artemisia annua L.(Qinghao). Molecules, 15(11), 76037698.

Cho, J.-Y., Park, K.-H., Hwang, D.Y., Chanmuang, S., Jaiswal, L., Park, Y.K., . . . Moon, J.-H. (2015). Antihypertensive effects of Artemisia scoparia waldst in spontaneously 
hypertensive rats and identification of angiotensin I converting enzyme inhibitors. Molecules, 20(11), 1978919804.

Efferth, T. (2007). Willmar Schwabe Award 2006: antiplasmodial and antitumor activity of artemisinin-from bench to bedside. Planta medica, 73(04), 299309.

Gomha, S.M., Riyadh, S.M., Mahmmoud, E.A. \& Elaasser, M.M. (2015). Synthesis and anticancer activities of thiazoles, 1, 3-thiazines, and thiazolidine using chitosan-graftedpoly (vinylpyridine) as basic catalyst. Heterocycles, 91(6), 1227-1243.

Gordon, M.M., Van Derveer, D. \& Zalkow, L.H. (1981). New germacranolides from Artemisia herba alba. X-ray crystal structures of $3 \beta, 8 \alpha$-dihydroxy$6 \beta \mathrm{H}, 7 \alpha \mathrm{H}, 11 \beta \mathrm{H}$-germacran-4 (14), 9 (10)-dien-6, 12-olide and the corresponding 3-oxo-olide. Journal of Natural Products, 44(4), 432-440.

Ivanescu, B., Miron, A.\& Corciova, A. (2015). Sesquiterpene lactones from Artemisia genus: biological activities and methods of analysis. J. Anal. Methods Chem, 21(10.1155), 2015.

Migahid, A.M. (1978). Flora of saudi Arabia. Mohamed, T.A., Hegazy, M.-E. F., Abd El Aty, A.A., Ghabbour, H. A., Alsaid, M. S., Shahat, A. A., \& Paré, P. W. (2017). Antimicrobial sesquiterpene lactones from Artemisia sieberi. Journal of Asian Natural Products Research, 1-9.

Mosmann, T. (1983). Rapid colorimetric assay for cellular growth and survival: application to proliferation and cytotoxicity assays. $J$ Immunol Methods, 65(1-2), 55-63.

Obolskiy, D., Pischel, I., Feistel, B., Glotov, N.\& Heinrich, M. (2011). Artemisia dracunculus L.(tarragon): a critical review of its traditional use, chemical composition, pharmacology, and safety. Journal of agricultural and food chemistry, 59(21), 11367-11384.

Park, S.-H., Cui, X., Ahn, D., Lee, E. B., Cha, D. S., Jeon, H., . . Kim, D.K. (2014). Anti-oxidative Activities of 3'Hydroxygenkwanin from the Flower Buds of Daphne genkwa in Caenorhabditis elegans. Natural Product Sciences, 20(2), 80-85.

Saadali, B., Boriky, D., Blaghen, M., Vanhaelen, M.\& Talbi, M. (2001). Alkamides from Artemisia dracunculus. Phytochemistry, 58(7), 1083-1086.

Stebbings, S., Beattie, E., McNamara, D.\& Hunt, S. (2015). A pilot randomized, placebo-controlled clinical trial to investigate the efficacy and safety of an extract of Artemisia annua administered over 12 weeks, for managing pain, stiffness, and functional limitation associated with osteoarthritis of the hip and knee. Clinical rheumatology, 1-8.

Wright, C.W. (2005). Artemisia. London and New York: Taylor and Francis;.

Zeng, W. \& Quesheng, Z.Q., Liang, H.(2014). Flavonoids from Artemisia gmelinii Web. ex Stechm. Journal of Chinese Pharmaceutical Sciences, 23(7), 496499. 


\section{النشاط المقاوم للخلايا السرطانية لمركبين معزولين من نبات الأرتيميزيا سيبيري}

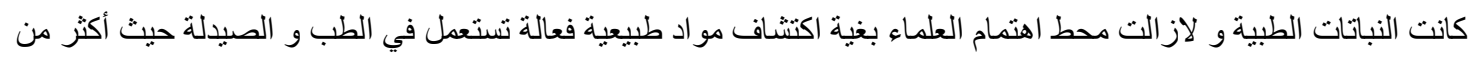

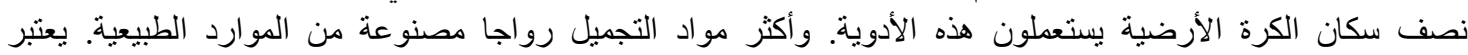

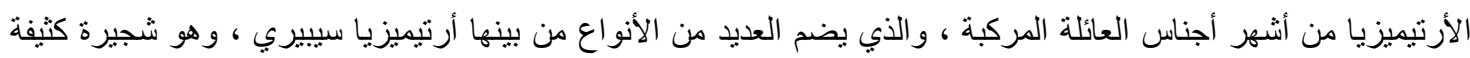

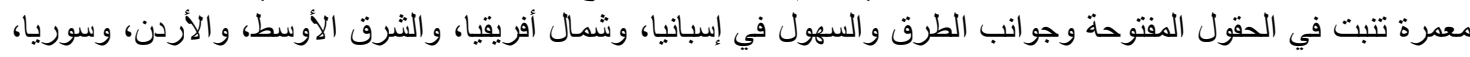

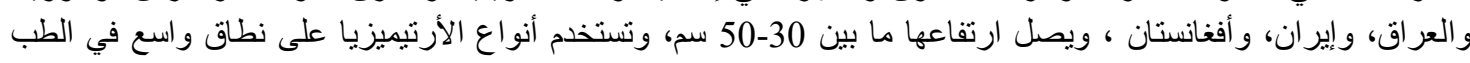

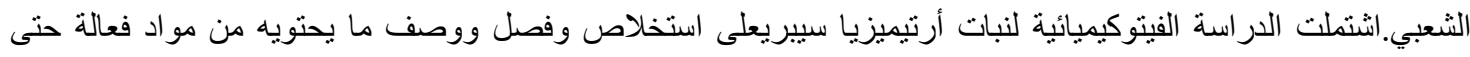

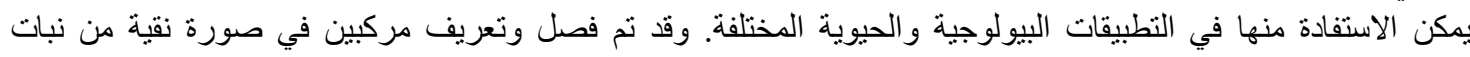
الأرتيميزيا سيبيري.

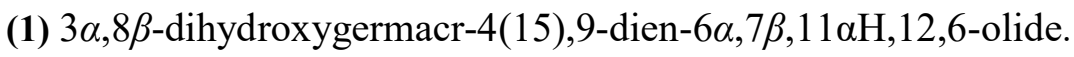

(2) flavonoid 3'-hydroxy-genkwanin.<smiles>C=C(C)C[C@@H]1OC(=O)[C@H](C)[C@H]1[C@H](O)/C=C(/C)CCCC(C)O</smiles>

(1)<smiles>COc1cc(O)c2c(=O)cc(-c3ccc(O)c(O)c3)oc2c1</smiles>

(2)

\section{دراسة الفاعلية البيولوجية للمركبات المفصولة. \\ أولا : مقاومة بعض الخلايا السرطانية}

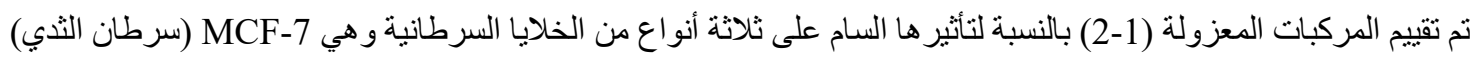

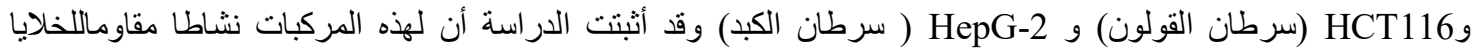

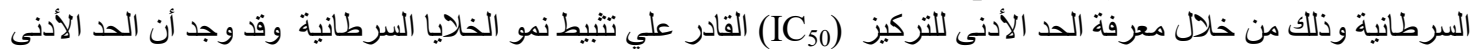
للمركبات المعزولة كالآتي:

$$
\text { بالنسبة للمركب (1) } 146 \text { ، } 173 \text { ، } 13.6 \text { ، } 115 \text { ، } 112.5 \text { ميكرو جر ام لكل ملي للمركبة } 15.4 \text { ميكرو جرام لكل ملي }
$$

وبالتالي نتوقع من اختبار السمية الخلوية أن المركبات المعزولة بتركيزات عالية من المحتمل أن تكون بمثابة أدوية مضادة للسرطان. 